\title{
Dystonia, facial dysmorphism, intellectual disability and breast cancer associated with a chromosome $13 q 34$ duplication and overexpression of TFDP1: case report
}

Mariana Moscovich¹, Mark S LeDoux², Jianfeng Xiao², Garrett L Rampon², Satya R Vemula², Ramon L Rodriguez', Kelly D Foote ${ }^{3}$ and Michael S Okun ${ }^{1,3^{*}}$

\begin{abstract}
Background: Dystonia is a movement disorder characterized by involuntary sustained muscle contractions causing twisting and repetitive movements or abnormal postures. Some cases of primary and neurodegenerative dystonia have been associated with mutations in individual genes critical to the $G_{1}-S$ checkpoint pathway (THAP1, ATM, CIZ1 and TAF1). Secondary dystonia is also a relatively common clinical sign in many neurogenetic disorders. However, the contribution of structural variation in the genome to the etiopathogenesis of dystonia remains largely unexplored.

Case presentation: Cytogenetic analyses with the Affymetrix Genome-Wide Human SNP Array 6.0 identified a chromosome 13q34 duplication in a 36 year-old female with global developmental delay, facial dysmorphism, tall stature, breast cancer and dystonia, and her neurologically-normal father. Dystonia improved with bilateral globus pallidus interna (GPi) deep brain stimulation (DBS). Genomic breakpoint analysis, quantitative PCR (qPCR) and leukocyte gene expression were used to characterize the structural variant. The 218,345 bp duplication was found to include ADPRHL1, DCUN1D2, and TMCO3, and a 69 bp fragment from a long terminal repeat (LTR) located within Intron 3 of TFDP1. The 3 ' breakpoint was located within Exon 1 of a TFDP1 long non-coding RNA (NR_026580.1). In the affected subject and her father, gene expression was higher for all three genes located within the duplication. However, in comparison to her father, mother and neurologically-normal controls, the affected subject also showed marked overexpression (2X) of the transcription factor TFDP1 (NM_007111.4). Whole-exome sequencing identified an SGCE variant (c.1295G > A, p.Ser432His) that could possibly have contributed to the development of dystonia in the proband. No pathogenic mutations were identified in BRCA1 or BRCA2.
\end{abstract}

Conclusion: Overexpression of TFDP1 has been associated with breast cancer and may also be linked to the tall stature, dysmorphism and dystonia seen in our patient.

Keywords: Dystonia, Chromosome 13q34, Duplication, TFDP1, Breast cancer, G 1 -S Checkpoint pathway

\footnotetext{
* Correspondence: okun@neurology.ufl.edu

${ }^{1}$ Center for Movement Disorders and Neurorestoration, Department of

Neurology, University of Florida College of Medicine, 100 S Newell Drive, Room L3-101, Gainesville, FL 32610, USA

${ }^{3}$ Center for Movement Disorders \& Neurorestoration, Department of Neurosurgery, University of Florida, McKnight Brain Institute, $100 \mathrm{~S}$ Newell Drive, Room L2-100, Gainesville, FL 32610, USA

Full list of author information is available at the end of the article
} 


\section{Background}

Chromosome 13q34 amplifications have been reported in lung cancer [1], small bowel adenocarcinoma [2], hepatocellular carcinoma [3], squamous cell carcinoma of the esophagus [4], and breast cancer [5,6]. Overexpression of genes in this region, particularly TFDP1, may be causally associated with the development or progression of these malignancies [5,6]. TFDP1 encodes the transcription factor DP-1. DP-1 forms heterodimers with E2F family members to enhance their DNA-binding and promote transcription of E2F target genes. The E2F/DP-1 complex plays a critical role in the $\mathrm{G}_{1}-\mathrm{S}$ cell-cycle transition [7].

Numerous stimuli, including DNA damage, TGF $\beta$, replicative senescence, and contact inhibition, exert control over the $G_{1}-S$ checkpoint pathway $[8,9]$. Defects in this pathway have been associated with developmental defects, neurodegenerative disorders, cancer and dystonia [10-12]. In particular, five genes linked to dystonia appear to be involved upstream or downstream of DP-1 in the $\mathrm{G}_{1}-\mathrm{S}$ checkpoint pathway (ATM, CIZ1, TOR1A, THAP1 and $T A F 1)$. Autosomal recessive mutations of $A T M$ increase risk for malignancies and typically present as ataxia telangiectasia. However, some patients present with isolated dystonia [11]. Moreover, female carriers are at higher risk for breast cancer [13]. The encoded protein, ataxia telangiectasia mutated (ATM), activates p53 by phosphorylating the ubiquitin E3 ligase MDM2 [14]. Reduced neuronal expression of TAF1 is linked to a form of dystonia-parkinsonism known as Lubag or DYT3 [15]. TAF1 mediates degradation of p53 via phosphorylation at Thr-55 [16]. CIZ1 interacts with p21Cip1 [17]. TorsinA, the protein encoded by TOR1A, interferes with TGF $\beta$ signaling pathway [18]. Finally, the S-phase gene $R R M 1$ is a direct transcriptional target of THAP1 [19].

Herein, we report a unique patient with a chromosome 13q34 duplication, dystonia, dysmorphism, intellectual disability, psychosis, tall stature, and breast cancer. Gene expression studies suggest that one or more of these phenotypic features may be due to overexpression of TFDP1.

\section{Case presentation}

A 36 year-old right-handed Hispanic woman presented for evaluation of stiffness, painful muscle spasms, difficulty walking, falling, and abnormal involuntary hyperkinetic movements that had progressed over three years. She also reported decreased motivation, speech articulation problems, and difficulty with all activities of daily living as well as with handwriting. The chronology of proband's signs and symptoms is outlined in Table 1.

She was born by cesarean section and was noted to be hypoxemic but was delivered at full term. She was the fourth child in her family, and none of the other children had neurological disorders or cancer related illnesses. Her motor and cognitive development was delayed. She did not sit until after 6 months of age and did not walk until 18 months of age, and was enrolled in special education classes in the first grade.

Because of her tall stature at 7 years of age, a diagnosis of Marfan syndrome was suggested by her physicians but never confirmed with molecular genetic testing. She completed a total of 6 years of schooling. At 30 years of age, she developed a psychiatric disturbance with psychotic features. She became obsessed with popular rock and roll bands and experienced visual and auditory hallucinations. She was briefly hospitalized for psychosis, and was treated successfully for three years with risperidone (1 mg three times daily), valproic acid and buproprion. However, she then began to manifest what was described as choreoathetotic and dystonic movements in her left arm along with blepharospasm. She was treated with levetiracetam, carbamazepine, oxcarbamazepine, clonazepam, biperidone, haldoperidol, aripiprazole, topiramate, baclofen, carbidopa/levodopa, chlorpromazine, amantadine, trihexyphenidyl, and botulinum toxin injections. These medical treatments were only mildly beneficial, and her neurological condition progressively worsened with the appearance of hyperkinetic movements affecting her right arm and trunk.

At age 35, she was diagnosed with breast cancer during a routine physical examination. She underwent a radical right mastectomy with preservation of the areola and nipple. Serum prolactin levels were not obtained. She was treated with tamoxifen, post-operatively, and has shown no evidence of local recurrence or metastasis of her breast cancer. Pathology revealed an encapsulated mucinous carcinoma, grade I. The tumor cells inside mucous lakes expressed estrogen and progesterone receptors and did not over-express Her2/neu.

Her hyperkinetic movement disorder showed an initial modest response to tetrabenazine. However, dystonia gradually worsened with painful retrocollis and truncal dystonia. Over a period of 6 months, she lost 25 pounds and became profoundly debilitated by dystonia, spending most of her waking day lying face down.

Brain magnetic resonance image (MRI) was unremarkable and routine laboratory testing including a comprehensive metabolic profile was normal. A 24-hour urine copper for Wilson's disease was also normal. A 99mTcHMPAO single photon emission computed tomography (SPECT) showed asymmetric and decreased radiotracer uptake in basal ganglia regions including the caudate, putamen, and globus pallidus. Molecular cytogenetic analysis exposed a chromosome 13q34 duplication.

At age 36, general physical examination revealed facial dysmorphism with hypertelorism, down slanting palpebral fissures, mild ptosis and large low-set ears with mild posterior rotation (Figure 1). Other clinical features 
Table 1 Chronology of proband's signs and symptoms

\begin{tabular}{|c|c|}
\hline 1976 & Born by cesarean section at full term. \\
\hline \multirow[t]{3}{*}{ 1976-1986 } & Did not sit until after 6 months of age and did not walk until 18 months of age. \\
\hline & Enrolled in special education classes in the first grade. \\
\hline & Developmental delay, Marfanoid features, dysmorphic features, strabismus, mitral valve prolapse were described by pediatrician. \\
\hline 2003-2007 & Appearance of psychiatric symptoms including psychosis treated with valproic acid, risperidone and buproprion. \\
\hline 2008 & $\begin{array}{l}\text { Movement disorder becomes manifest (choreoathetotic and dystonic movements in the left arm along with } \\
\text { blepharospasm) and is treated with levetiracetam, carbamazepine, oxcarbazepine, lorazepam, biperiden, haloperidol, } \\
\text { aripiprazole, topiramate, chlorpromazine, carbidopa/levodopa, baclofen, amantadine, trihexyphenidyl, botulinum toxin } \\
\text { injections, and tetrabenazine. }\end{array}$ \\
\hline 2009 & $\begin{array}{l}\text { Despite medical treatment and discontinuation of dopamine blocking drugs, neurological condition progressively worsens } \\
\text { with hyperkinetic movements appearing in the right arm and trunk. }\end{array}$ \\
\hline \multirow[t]{6}{*}{2010} & $\begin{array}{l}\text { Mucinous carcinoma of the right breast diagnosed and treated with a modified radical mastectomy with skin preservation } \\
\text { and immediate reconstruction with breast prosthesis. }\end{array}$ \\
\hline & Histology report shows no residual tumor at tissue margins and lymph nodes free of tumor. \\
\hline & Post-operative treatment with tamoxifen. \\
\hline & Worsening of the dystonia with appearance of truncal dystonia including painful retrocollis. \\
\hline & Difficulty staying upright for even short periods. \\
\hline & Weight loss of 25 pounds. \\
\hline \multirow[t]{5}{*}{2011} & Implantation of bilateral globus pallidus internus electrodes for deep brain stimulation. \\
\hline & Marked improvement of dystonia 4 months after surgery. \\
\hline & Subject able to feed herself, sit upright and walk. \\
\hline & Significant improvements in neck pain. \\
\hline & $\begin{array}{l}\text { Revision of left and right pulse generators, and replacement of left extension cable after lead fracture due to twiddler } \\
\text { syndrome (obsessively moving the generators in the chest leading to device fracture). }\end{array}$ \\
\hline 2013 & Facial dystonia markedly improved. Sustained control of dystonia with deep brain stimulation. \\
\hline
\end{tabular}

included hirsutism, low anterior hairline, micrognathia, brevicollis, scoliosis, arachnodactyly, tall stature $(182.9 \mathrm{~cm})$, and a weight of $62.3 \mathrm{~kg}$ (body mass index =18.6). On neurological examination, she was moderately inattentive. No primitive reflexes were noted. She scored a 19/30 on the Montreal Cognitive Assessment (MoCA). MoCA scores of 26 and higher are considered normal. Although cranial nerves were all normal, speech was mildly dysarthric, and facial dystonia was overt. Muscle strength testing was normal. There was no focal atrophy or fasciculations. There was no obvious upper extremity ataxia although testing of coordination was limited by the presence of dystonia. Gait was broad-based and ataxic, and she required assistance to walk. Walking was also compromised by dystonic posturing of her trunk and arms. Sensory testing was normal. Cervical dystonia was manifest as severe retrocollis. Truncal and bilateral arm dystonia had a clear action component and worsened during movement, particularly walking. No contractures were present in the arms or legs. A score of 37 was recorded for the pre-operative Unified Dystonia Rating Scale (UDRS, maximum score is 112).

The proband underwent bilateral globus pallidus internus (GPi) deep brain stimulation (DBS). She gradually improved and after 4 months her facial dystonia was markedly better and she became able to feed herself. She could sit upright and tolerated sitting for progressively longer periods of time. Both subjective and objective improvements in postural stability, gait, and retrocollis were noted. Neck pain and upper limb dystonia were significantly improved. The 4-month post-operative score on the UDRS was 23. However, shortly after this period of clinical improvement, she experienced hardware malfunction due to lead wire fractures caused by her twiddling the implantable pulse generators (IPGs). The lead connectors were replaced and the IPGs tacked down to prevent twiddling, and her dystonia improved once again. Her outpatient clinical course has been compromised by dysphagia and hospitalizations for treatment of aspiration pneumonia which ultimately required placement of a percutaneous endoscopic gastrostomy (PEG) tube.

The proband's parents and two brothers were neurologically normal and showed no dysmorphic features. Her mother and father were 167.6 and $170.2 \mathrm{~cm}$ tall, respectively. There was no history of dystonia or breast cancer in any first or second degree relative.

All human studies were performed in accordance with institutional review board guidelines and the Helsinki Declaration. Written informed consent for genetic studies 


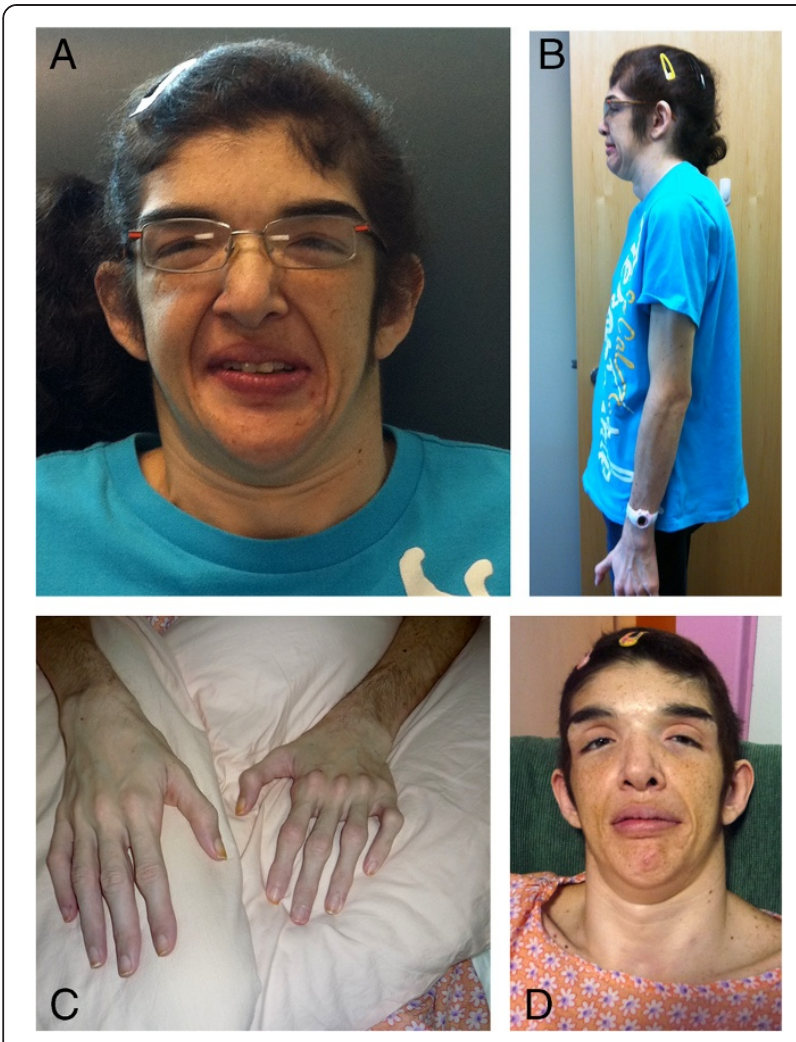

Figure 1 Frontal (A) and lateral (B) photographs 4 months after GPi DBS show the presence of mild facial dystonia and dysmorphic features. C) Arachnodactyl and hirsutism. D) Virtual resolution of facial dystonia 2 yrs after GPi DBS.

and publication of clinical data was obtained from the patient, her parents and neurologically-normal controls. All genetic analyses were approved by the University of Tennessee Health Science Center Institutional Review Board (\#01-07346-XP). The proband and her parents were examined at the Center for Movement Disorders and Neurorestoration, Department of Neurology, University of Florida, and were part of the IRB approved INFORM clinical database. The proband's siblings live outside the United States and were unable to complete a study visit at the University of Florida. However, the siblings were interviewed via Skype (www.skype.com). Recruitment of neurologically-normal controls has been described previously [20].

\section{Identification of the duplication}

Clinical cytogenetic analyses were performed by Quest Diagnostics (Madison, NJ, USA) on DNA derived from whole blood using the Affymetrix Genome-Wide Human SNP Array 6.0. The Affymetrix 6.0 microarray contains over 1.8 million probes, including 900,000 copy number probes and 900,000 SNP probes. The average inter-probe distance is 700 base pairs. Thresholds for genome-wide screening were set at $>200 \mathrm{~kb}$ for gains, $>50 \mathrm{~kb}$ for losses and $10 \mathrm{Mb}$ for segments of homozygosity. A $\sim 225 \mathrm{~kb}$ gain of unclear clinical significance was detected in the proband at 13q34. Four genes were involved in the genomic alteration: ADPRHL1, DCUN1D2, TMCO3 and TFDP1. Follow-up analyses of the parents using the same array indicated that the variant was of paternal origin. The classic TOR1A $\triangle$ GAG mutation was excluded with Sanger sequencing.

For genomic breakpoint analysis and confirmation of copy numbers, DNA was extracted from peripheral blood leucocytes using Roche's DNA Isolation Kit for Mammalian Blood (Indianapolis, IN, USA). DNA quantity and quality were analyzed with a NanoDrop ND-1000 spectrophotometer (Wilmington, DE, USA) and agarose gel electrophoresis. Quantitative PCR (qPCR) primers and probes were designed via Roche's Universal Probe Library to encompass the estimated boundary regions (Additional file 1). qPCR was performed using $20 \mathrm{ng}$ of template DNA and $200 \mathrm{nM}$ of each primer in a $10-\mu \mathrm{l}$ reaction volume with the LightCycler ${ }^{\mathrm{Tm}} 480$ system and Universal Taqman ${ }^{\circledR}$ probes (Roche). The following cycling conditions were employed: $95^{\circ} \mathrm{C}$ for $5 \mathrm{~min} ; 45$ cycles at $95^{\circ} \mathrm{C}$ for $10 \mathrm{~s}$, $60^{\circ} \mathrm{C}$ for $30 \mathrm{~s}$, and $72^{\circ} \mathrm{C}$ for $12 \mathrm{~s}$. Copy numbers were referenced to an endogenous control (RPPH1) and 9 neurologically-normal unrelated subjects. All assays were done in triplicate and means were used for comparisons. Long-range PCR was then performed using primers outside the boundary regions of the duplication (for example, Dup237_p13F and Dup025_p23R in Additional file 1). After agarose gel purification, PCR products were sequenced in the forward and reverse directions on an Applied Biosystems 3130XL Genetic Analyzer (Carlsbad, CA, USA).

Relative quantitative reverse-transcriptase PCR (QRTPCR) was done to analyze the expression levels of genes located within or near the structural variant. In brief, Ambion's LeukoLOCK ${ }^{\mathrm{mm}}$ Total RNA Isolation System and TRI Reagent ${ }^{\circledR}$ were used to isolate RNA from peripheral blood leukocytes. Leukocyte RNA was not available for the proband's siblings. Reverse transcription was performed with Ambion's RETROscript ${ }^{\mathrm{mi}}$ kit using $500 \mathrm{ng}$ total RNA as template along with random oligonucleotide primers. The reaction mixtures were incubated at $44^{\circ} \mathrm{C}$ for $1 \mathrm{hr}$ and then at $92^{\circ} \mathrm{C}$ for $10 \mathrm{~min}$. QRT-PCR was performed using the LightCycler ${ }^{\mathrm{TM}} 480$ system with gene specific primers (Additional file 1) and Universal Taqman ${ }^{\circledR}$ probes (Roche) for 4 genes involved in the duplication region (ADPRHL1, DCUN1D2, TMCO3, and TFDP1), TFDP1 long non-coding RNA (lncRNA), 1 gene near the duplication (GRTP1), and the endogenous control (PPID), which encodes $40 \mathrm{kDa}$ peptidyl-prolyl cis-trans isomerase D (cyclophilin D). All assays were performed in triplicate and means were used for comparisons. 
Identification of exact breakpoints was facilitated by mapping flanking SNPs and Affymetrix copy number (CN) probes for the 13q34 duplication in both the proband and her father (bolded were predicted by Quest Diagnostics to be within the gain): SNP_A-1803536 (Chr13:114022946), CN_634194 (Chr13:114023445), SNP_ A-8304155 (Chr13:114023625), CN_091810(Chr13:1140 25424), CN_634195(Chr13:114027458), SNP_A-22610 43(Chr13:114030927), SNP_A-8505553(Chr13:1142498 07), CN_091834(Chr13:114249942), CN_636300 (Chr13: 114257699), and SNP_A-2105146(Chr13:114257910). With qPCR of genomic DNA we were able to confirm duplication of ADPRHL1, DCUN1D2, and TMCO3, and showed that GRTP1 and TFDP1 were, in fact, outside the duplicated segment (Figure 2 and Table 2). Fold changes of approximately $1.5 \times$ for ADPRHL1, DCUN1D2 and TMCO3 were consistent with a duplication involving one allele of each gene. Stepwise long-range PCR and Sanger sequencing allowed us to identify the $5^{\prime}$ and 3 ' breakpoints (Chr13:114,020,670 and Chr13:114,239,014) in the affected subject and her father (Figure 2). The duplicated segments were separated by a 69 bp fragment. Nucleotide query with Basic Local Alignment Search Tool (BLAST) suggested that this $69 \mathrm{bp}$ fragment (Chr13:114,275,816-884) was duplicated from Intron 3 of TFDP1, $36 \mathrm{~kb} \mathrm{3'}$ to its location between the larger duplicated segment. A single deoxyadenosine (A) was detected $5^{\prime}$ to the smaller 69 bp fragment. The 5' breakpoint (Chr13:114,020,670) was located 3' to the end of GRTP1 (Chr13:114,018,463) and the 3' breakpoint (Chr13:114,239,014) was located $5^{\prime}$ to the start of TFDP1 (NM_007111.4: Chr13:114,239,056), within Exon 1 of a TFDP1 long non-coding RNA (NR_026580.1). The 69 bp fragment showed $100 \%$ sequence identity to a long terminal repeat (LTR) of the endogenous retrovirus family K (ERVK) located in Intron 3 of TFDP1. This LTR is 983 nt in length (Chr13:114,275,682-114,276,664). Collectively, the complex structural variant identified in our patient and her father can be denoted as NC_000013.10: g.114,020,670_114,239,014dup218,345;g.114,239,014_11 $4,239,015 \operatorname{ins}\left(A+114,275,816 \_114,275,884\right)$. This variant was also identified in one of the proband's three brothers (Table 3). It has not been reported in the Database of Genomic Variants (http://projects.tcag.ca/variation/).

Relative gene expression in leukocytes is shown in Table 4. In the affected subject and her father, relative RNA expression was higher for all three genes located within the duplication region (ADPRHL1, DCUN1D2 and TMCO3). However, in comparison to her mother and neurologically normal controls, the affected subject showed marked overexpression $(>2 \times)$ of $A D P R H L 1$ and TMCO3. In contrast, gene expression in the father was approximately $0.5 \times$ above control values for ADPRHL1, DCUN1D2 and TMCO3, compatible with the presence of three copies of these genes. Of particular note, TFDP1 and TFDP1 lncRNA showed strong leukocyte overexpression in the affected subject but not in her father or mother. For gene expression analyses, all assays were performed in triplicate and means were used for comparisons.

\section{Exome sequencing and variant analysis}

To identify other genetic factors that could cause or contribute to risk of developing breast cancer and/or dystonia, in-solution whole-exome capture and massively parallel sequencing using the Agilent SureSelect XT All Exon Kit $51 \mathrm{Mb}$ (Santa Clara, CA, USA) was used to examine the proband's exome. Three micrograms of genomic DNA from the subject was sheared to yield 100-450 bp fragments. Sheared DNA was then subjected to Illumina paired-end library preparation followed by enrichment for target sequences (Agilent SureSelect ${ }^{\mathrm{XT}}$ Automated Target Enrichment for Illumina Paired-End Multiplexed Sequencing). Enriched DNA fragments

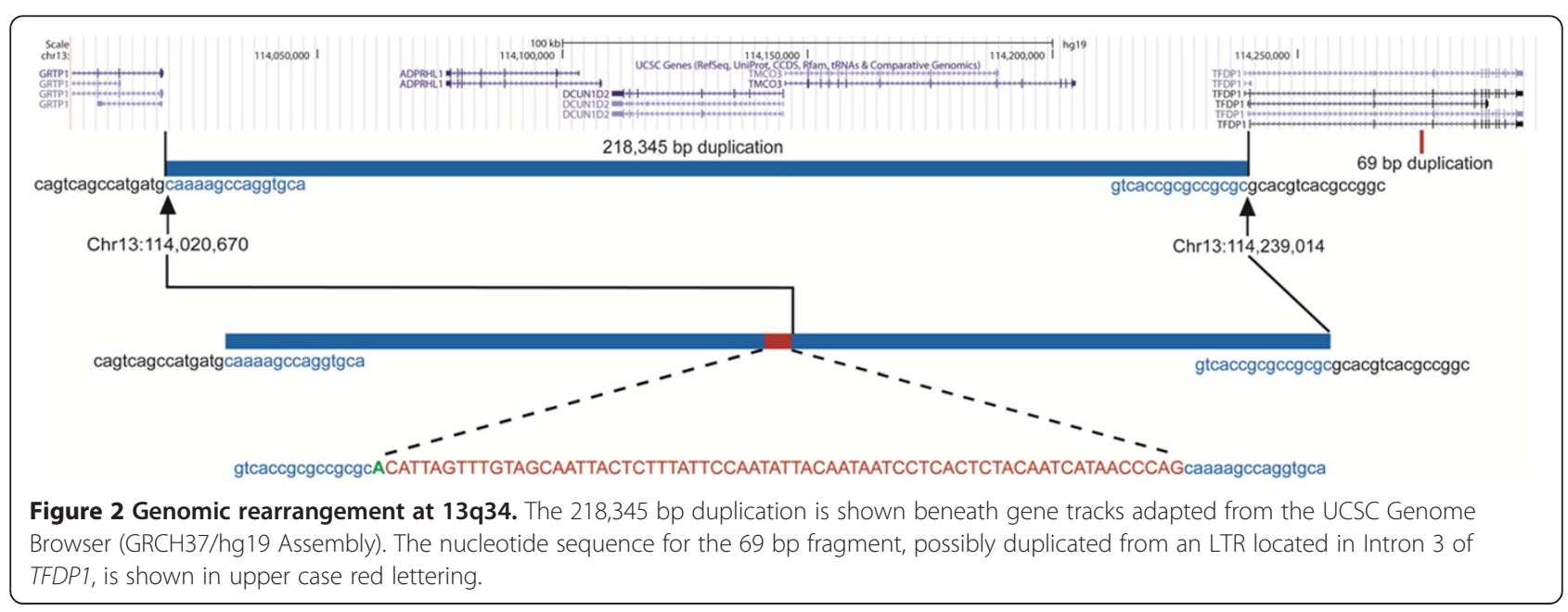


Table 2 Quantitative PCR of genomic DNA

\begin{tabular}{llcccc}
\hline Primers & Location (13q34) & $\begin{array}{c}\text { Normal } \\
\text { controls }\end{array}$ & \multicolumn{3}{c}{ Subject fold change } \\
\cline { 5 - 7 } & NC_000013.10 & $\mathbf{( N = 9 )}$ & Patient & $\begin{array}{c}\text { Father } \\
\text { (carrier) }\end{array}$ & Mother \\
\hline Dup_018F/R & $114018980-9123$ & $1.00 \pm 0.13$ & 0.94 & 0.98 & 1.01 \\
Dup_023F/R & $114023386-3429$ & $1.00 \pm 0.15$ & 1.47 & 1.51 & 0.99 \\
Dup_025F/R & $114025267-5677$ & $1.00 \pm 0.17$ & 1.52 & 1.58 & 1.02 \\
Dup_041F/R & $114041257-1333$ & $1.00 \pm 0.12$ & 1.57 & 1.49 & 0.98 \\
Dup_228F/R & $114228694-8793$ & $1.00 \pm 0.18$ & 1.61 & 1.58 & 1.08 \\
Dup_237F/R & $114237214-7282$ & $1.00 \pm 0.09$ & 1.53 & 1.55 & 1.02 \\
Dup_241F/R & $114241291-1364$ & $1.00 \pm 0.16$ & 0.95 & 0.99 & 0.98 \\
Dup_249F/R & $114249685-9762$ & $1.00 \pm 0.10$ & 1.10 & 1.04 & 1.01 \\
Dup_257F/R & $114257807-7900$ & $1.00 \pm 0.11$ & 1.08 & 0.99 & 1.00 \\
\hline
\end{tabular}

were sequenced on Illumina's HiSeq 2000 platform as paired-end 100 base reads (Otogenetics Co., Norcross, GA, USA) and reads were mapped to the human reference genome with NextGENe ${ }^{\circledR}$ (SoftGenetics, State College, PA, USA).

Over $99.7 \%$ of exons were covered at $\geq 2 \times$ and $97.6 \%$ of exons were covered at $\geq 20 \times$. To maximize the chances of detecting a pathogenic variant, base changes occurring in two or more reads were classified as variants for downstream analyses. We focused on genes associated with either breast cancer or dystonia (Additional file 2). The pathogenicity of non-synonymous single amino acid substitutions was interrogated with six in silico tools: PolyPhen-2, MutationTaster, $\mathrm{SIFT}_{\text {new }}, \mathrm{LRT}_{\text {new }}$ (Likelihood Ratio Test), PhyloP ${ }_{\text {new }}$, and ClustalW2 [21-23]. Sequence variants in SGCE, BRCA1, and XRCC3 were confirmed by Sanger sequencing in the forward and reverse directions. We identified a novel variant in SGCE (c.1295G > A, p.Ser432His) that is unlikely to be pathogenic (Table 3). Although predicted to be damaging by
SIFT [24], p.Ser432His is poorly conserved [22] and classified as "benign" and "polymorphism" by Polyphen-2 [25] and MutationTaster [26], respectively. Whole exome sequencing also identified a CIZ1 polymorphism that has not been associated with dystonia. Polymorphisms (dbSNP) were found in 16/25 breast cancer associated genes (Additional file 2). Two of these (BRCA1, rs799917; and $X R C C 3$, rs861539) have shown potential but inconclusive associations with breast cancer $[27,28]$.

\section{Discussion}

Dystonia is a neurological disorder characterized by involuntary sustained muscle contractions producing abnormal postures, twisting and repetitive abnormal movements, and sometimes painful muscle contractions. During dystonic movements, agonist and antagonist muscles co-contract in abnormal patterns. Dystonia is typically classified into primary, secondary, heredodegenerative diseases with dystonia, and dystonia-plus etiological categories [29]. Mutations in TOR1A, THAP1, CIZ1, $A N O 3, G N A L$ and TUBB4A have been associated with some cases of primary dystonia [12,20,23,30-33]. However, the genetic etiologies for most patients with primary dystonia remain unknown. The dystonia-plus category includes the myoclonus-dystonia syndrome (MDS) secondary to $S G C E$ mutations. Nearly all affected individuals have myoclonus and 50 to $65 \%$ manifest dystonia, typically in the neck and arms. Depression and anxiety are important non-motor features of MDS. Although our proband did harbor a potentially pathogenic SGCE missense variant, other carriers in the pedigree were asymptomatic. Moreover, the anatomical distribution and onset age of the proband's dystonia were atypical for MDS.

Secondary dystonia is caused by exogenous factors such as medications, toxins, or brain damage that may result from head trauma and stroke. Drugs that block dopamine receptors, such as neuroleptics and antiemetics, can cause acute dystonic reactions or late-onset,

Table 3 Pedigree genotypes

\begin{tabular}{|c|c|c|c|c|c|c|}
\hline $\begin{array}{l}\text { Family } \\
\text { member }\end{array}$ & Age & Phenotype & $\begin{array}{l}13 q 34 \\
\text { Duplication }\end{array}$ & SGCE Exon 10 & $\begin{array}{l}\text { BRCA1, rs799917 } \\
\text { NC_000017: } \\
\text { g.41244936G > A }\end{array}$ & $\begin{array}{l}X R C C 3, \mathrm{rs} 861539 \\
\text { NC_000014: } \\
\text { g.104165753G > A }\end{array}$ \\
\hline Proband & 37 & $\begin{array}{l}\text { Generalized dystonia, } \\
\text { breast cancer, dysmorphism }\end{array}$ & Yes & $\begin{array}{l}\text { c.1294A > C (homozygous), } \\
\text { c.1295G > A (heterozygous) }\end{array}$ & heterozygous & heterozygous \\
\hline Father & 71 & Normal & Yes & $\begin{array}{l}\text { c.1294A > C (homozygous), } \\
\text { c.1295G > A (heterozygous) }\end{array}$ & heterozygous & wild-type \\
\hline Mother & 70 & Normal & No & c.1294A > C (homozygous) & heterozygous & heterozygous \\
\hline Brother & 47 & Normal & No & c.1294A > C (homozygous) & heterozygous & wild-type \\
\hline Brother & 46 & Normal & No & c.1294A > C (homozygous) & heterozygous & heterozygous \\
\hline Brother & 43 & Normal & Yes & $\begin{array}{l}\text { c.1294A > C (homozygous), } \\
\text { c.1295G > A (heterozygous) }\end{array}$ & heterozygous & heterozygous \\
\hline
\end{tabular}


Table 4 Relative leukocyte gene expression

\begin{tabular}{lllccc}
\hline Gene & $\begin{array}{l}\text { Location of } \\
\text { the gene }\end{array}$ & $\begin{array}{l}\text { Normal } \\
\text { controls } \\
\text { (N=9) }\end{array}$ & \multicolumn{3}{c}{ Subject fold change } \\
\cline { 5 - 6 } & & Patient & $\begin{array}{l}\text { Father } \\
\text { (carrier) }\end{array}$ & Mother \\
\hline ADPRHL1 P1 & Within & $1.00 \pm 0.18$ & 2.71 & 1.70 & 1.10 \\
ADPRHL1 P2 & duplication & $1.00 \pm 0.25$ & 2.26 & 1.70 & 1.10 \\
DCUN1D2 P1 & Within & $1.00 \pm 0.05$ & 1.48 & 1.61 & 0.95 \\
DCUN1D2 P2 & duplication & $1.00 \pm 0.19$ & 1.62 & 1.46 & 0.96 \\
TMCO3 P1 & Within & $1.00 \pm 0.13$ & 3.13 & 1.68 & 1.04 \\
TMCO3 P2 & duplication & $1.00 \pm 0.06$ & 2.69 & 1.59 & 1.21 \\
TFDP1 P1 & 3' to & $1.00 \pm 0.20$ & 1.95 & 1.05 & 1.25 \\
TFDP1 P2 & duplication & $1.00 \pm 0.16$ & 2.04 & 0.97 & 1.18 \\
TFDP1 & 3' to & $1.00 \pm 0.18$ & 2.01 & 0.93 & 1.20 \\
InCRNA P1 & duplication & & & & \\
TFDP1 & & $1.00 \pm 0.21$ & 2.15 & 0.95 & 1.11 \\
InCRNA P2 & & & & & \\
GRTP1 P1 & 5' to & $1.00 \pm 0.13$ & 1.08 & 0.89 & 1.26 \\
GRTP1 P2 & duplication & $1.00 \pm 0.10$ & 0.98 & 0.85 & 1.28 \\
\hline
\end{tabular}

persistent "tardive" dystonia, after months or years of treatment [34]. Tardive movement disorders are usually hyperkinetic and include classic tardive oral-buccal-lingual dyskinesias and tardive chorea, dystonia, tics, tremor and akathisia. The differentiation of tardive from primary dystonia can be difficult and categorization remains clinical as it was for our patient. In this regard, it is quite uncommon for patients with tardive dystonia to progressively worsen months after discontinuation of drugs that block dopamine receptors. Although the genetic susceptibility for developing tardive movement disorders has been poorly characterized, sequence variants in genes associated with primary dystonia could be risk factors [35,36]. For instance, a novel missense mutation in TOR1A (c.613 T > A) has been linked to adultonset lower facial and masticatory, possibly tardive, dystonia [35].

It is now well-established that GPi DBS exerts beneficial effects on many dystonia subtypes [34-41]. In general, current experience with DBS suggests that primary dystonias respond better than most secondary dystonias [42]. However, many reports indicate that tardive dystonia can show significant improvements with DBS [42].

The complex structural variant identified in our patient is of uncertain clinical significance since the three duplicated genes have not been associated with dystonia, intellectual disability or dysmorphism in human populations. Moreover, two clinically unaffected family members harbored the same variant. ADPRHL1 encodes an ADPribosyltransferase that transfers ADP-ribose from NAD + to target proteins. DCUN1D2 encodes a protein that may contribute to neddylation of cullin components of SCFtype E3 ubiquitin ligase complexes. Neddylation is the process by which $N E D D 8$ is conjugated to target proteins. NEDD8 is an ubiquitin-like modifier of protein function. Finally, TMCO3 encodes a transmembrane protein that probably functions as a $\mathrm{Na}^{+} / \mathrm{H}^{+}$antiporter. Chromosome 13q34 has, however, been linked to cancer, and, in Chinese, harbors a quantitative trait locus for physical height [43].

Pathogenic structural variants can be inherited from normal parents [44-47]. Penetrance values have been calculated for some of the more common structural variants and, for example, can range from $10.4 \%$ for $15 \mathrm{q} 11.2$ deletions to $62.4 \%$ for distal $16 \mathrm{p} 11.2$ deletions [47]. Some structural variants may be associated with several phenotypes and penetrance is phenotype specific. Ultimately, other genetic and environmental factors contribute to penetrance and associated phenotypes. In the case of our proband, neuroleptic exposure may have increased her risk for breast cancer [48]. However, whole-exome sequencing did not expose pathogenic non-structural variants in genes associated with either breast cancer or dystonia.

In our patient with dystonia and dysmorphism, it is possible that the presence of the breakpoint within the upstream promoter region of TFDP1 (NM_007111.4) is responsible for altered expression of this transcription factor. The breakpoint could abrogate the effects of 5' repressor regions on TFDP1 expression. Over-expression of the TFDP1 lncRNA could have also contributed to this effect since some lncRNAs have been shown to play important roles in transcriptional regulation [49]. In theory, the consequences of the breakpoint on TFDP1 expression could be gender dependent. In this regard, TFDP1 is part of the estrogen receptor ER $\alpha$ regulatory network [50]. Epistasis and epigenetics (DNA methylation or histone deacetylation) are additional mechanistic considerations [51] that could explain why the father and brother are asymptomatic carriers of the structural variant while the proband manifests dystonia due to overexpression of TFDP1. Conversely, TFDP1 may have played no causal role in our patient's dystonia and other clinical manifestations.

\section{Conclusions}

This is the first report to describe a potential connection between TFDP1 and dystonia. Moreover, our analyses suggest that a TFDP1 lncRNA (NR_026580.1) could play a role in regulating TFDP1 expression. Our genetic findings are compatible with numerous previous studies which have consistently identified a link between chromosome $13 \mathrm{q} 34$ and cancer. Further studies in large case-control cohorts will be needed to confirm possible associations between chromosome 13q34 and dystonia. 


\section{Consent}

Written informed permission for use and disclosure of this families protected health information for research purposes and informed consent was obtained from the patient for publication of this case report and any accompanying images. Copies of the consents are available for review by the Editor-in-Chief of this journal.

\section{Additional files}

\section{Additional file 1: Primers used for PCR, QRT-PCR, $\mathrm{PPCR}$, and Sanger sequencing. \\ Additional file 2: Major genes associated with breast cancer.}

\section{Competing interests}

The authors declare that they have no competing interests.

\section{Authors' contributions}

All authors reviewed the manuscript critically for its content, revised and edited it, and approved the final version. Additionally, specific author contributions are as follows: JX, GLR, SRV and MSL performed the genetic analyses; MM, RLR, KDF and MSO treated the patient and collected clinica data; MSL and MSO conceptualized, designed and coordinated the study; and MM, MSO and MSL generated the first draft of the manuscript. All authors read and approved the final manuscript.

\section{Acknowledgments}

The authors are grateful to the patient and her parents who made this report possible. At the University of Tennessee Health Science Center, this study was supported by the Neuroscience Institute (MSL), Tyler's Hope (MSL), Dystonia Medical Research Foundation (MSL), NIH grant R01NS069936 (MSL), and the NIH Dystonia Coalition Pilot Projects Program (U54NS065701). This study was supported by grants from Tyler's Hope for a Dystonia Cure.

\section{Author details}

${ }^{1}$ Center for Movement Disorders and Neurorestoration, Department of Neurology, University of Florida College of Medicine, $100 \mathrm{~S}$ Newell Drive, Room L3-101, Gainesville, FL 32610, USA. 'Department of Neurology, University of Tennessee Health Science Center, 855 Monroe Avenue, Suite 415 Link Building, Memphis, Tennessee 38163, USA. ${ }^{3}$ Center for Movement Disorders \& Neurorestoration, Department of Neurosurgery, University of Florida, McKnight Brain Institute, 100 S Newell Drive, Room L2-100, Gainesville, FL 32610, USA.

Received: 7 September 2012 Accepted: 3 July 2013 Published: 13 July 2013

\section{References}

1. Castillo SD, Angulo B, Suarez-Gauthier A, Melchor L, Medina PP, Sanchez-Verde L, Torres-Lanzas J, Pita G, Benitez J, Sanchez-Cespedes M: Gene amplification of the transcription factor DP1 and CTNND1 in human lung cancer. J Pathol 2010, 222(1):89-98.

2. Diosdado B, Buffart TE, Watkins R, Carvalho B, Ylstra B, Tijssen M, Bolijn AS, Lewis F, Maude K, Verbeke $C$, et al: High-resolution array comparative genomic hybridization in sporadic and celiac disease-related small bowel adenocarcinomas. Clin Cancer Res 2010, 16(5):1391-1401.

3. Yasui $K$, Arii S, Zhao C, Imoto I, Ueda M, Nagai H, Emi M, Inazawa J: TFDP1, CUL4A, and CDC16 identified as targets for amplification at 13q34 in hepatocellular carcinomas. Hepatol 2002, 35(6):1476-1484.

4. Shinomiya T, Mori T, Ariyama Y, Sakabe T, Fukuda Y, Murakami Y, Nakamura Y, Inazawa J: Comparative genomic hybridization of squamous cell carcinoma of the esophagus: the possible involvement of the DPI gene in the 13q34 amplicon. Genes Chromosomes Cancer 1999, 24(4):337-344.

5. Abba MC, Fabris VT, Hu Y, Kittrell FS, Cai WW, Donehower LA, Sahin A Medina D, Aldaz CM: Identification of novel amplification gene targets in mouse and human breast cancer at a syntenic cluster mapping to mouse ch8A1 and human ch13q34. Cancer Res 2007, 67(9):4104-4112.
6. Melchor L, Saucedo-Cuevas LP, Munoz-Repeto I, Rodriguez-Pinilla SM, Honrado E, Campoverde A, Palacios J, Nathanson KL, Garcia MJ, Benitez J: Comprehensive characterization of the DNA amplification at 13q34 in human breast cancer reveals TFDP1 and CUL4A as likely candidate target genes. Breast Cancer Res 2009, 11(6):R86.

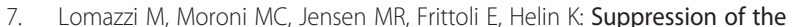
p53- or pRB-mediated G1 checkpoint is required for E2F-induced S-phase entry. Nat Genet 2002, 31(2):190-194.

8. Ravitz MJ, Wenner CE: Cyclin-dependent kinase regulation during G1 phase and cell cycle regulation by TGF-beta. Adv Cancer Res 1997, 71:165-207.

9. Talluri S, Isaac CE, Ahmad M, Henley SA, Francis SM, Martens AL, Bremner R, Dick FA: A G1 checkpoint mediated by the retinoblastoma protein that is dispensable in terminal differentiation but essential for senescence. Mol Cell Biol 2010, 30(4):948-960.

10. Hoche F, Seidel K, Theis M, Vlaho S, Schubert R, Zielen S, Kieslich M: Neurodegeneration in ataxia telangiectasia: what is new? What is evident? Neuropediatrics 2012, 43(3):119-129.

11. Saunders-Pullman R, Raymond D, Stoessl AJ, Hobson D, Nakamura K, Pullman S, Lefton D, Okun MS, Uitti R, Sachdev R, et al: Variant ataxia-telangiectasia presenting as primary-appearing dystonia in Canadian Mennonites. Neurol 2012, 78(9):649-657.

12. Xiao J, Uitti RJ, Zhao Y, Vemula SR, Perlmutter JS, Wszolek ZK, Maraganore DM, Auburger $\mathrm{G}$, Leube B, Lehnhoff $\mathrm{K}$, et al: Mutations in $\mathrm{ClZ1}$ cause adult onset primary cervical dystonia. Ann Neurol 2012, 71(4):458-469.

13. Swift M, Lukin JL: Breast cancer incidence and the effect of cigarette smoking in heterozygous carriers of mutations in the ataxia-telangiectasia gene. Cancer Epidemiol Biomarkers Prev 2008, 17(11):3188-3192.

14. Cheng $\mathrm{Q}$, Chen $\mathrm{L}, \mathrm{Li}$ Z, Lane WS, Chen J: ATM activates $\mathrm{p} 53$ by regulating MDM2 oligomerization and E3 processivity. EMBO J 2009, 28(24):3857-3867.

15. Makino S, Kaji R, Ando S, Tomizawa M, Yasuno K, Goto S, Matsumoto S, Tabuena MD, Maranon E, Dantes M, et al: Reduced neuron-specific expression of the TAF1 gene is associated with X-linked dystonia-parkinsonism. Am J Hum Genet 2007, 80(3):393-406.

16. Li HH, Li AG, Sheppard HM, Liu X: Phosphorylation on Thr-55 by TAF1 mediates degradation of p53: a role for TAF1 in cell G1 progression. Mol Cell 2004, 13(6):867-878.

17. Coverley D, Marr J, Ainscough J: Ciz1 promotes mammalian DNA replication. J Cell Sci 2005, 118(Pt 1):101-112.

18. Koh YH, Rehfeld K, Ganetzky B: A Drosophila model of early onset torsion dystonia suggests impairment in TGF-beta signaling. Hum Mol Genet 2004, 13(18):2019-2030.

19. Cayrol C, Lacroix C, Mathe C, Ecochard V, Ceribelli M, Loreau E, Lazar V, Dessen $P$, Mantovani R, Aguilar L, et al: The THAP-zinc finger protein THAP1 regulates endothelial cell proliferation through modulation of pRB/E2F cell-cycle target genes. Blood 2007, 109(2):584-594.

20. Xiao J, Zhao Y, Bastian RW, Perlmutter JS, Racette BA, Tabbal SD, Karimi M, Paniello RC, Wszolek ZK, Uitti RJ, et al: Novel THAP1 sequence variants in primary dystonia. Neurol 2010, 74(3):229-238.

21. Liu X, Jian X, Boerwinkle E: dbNSFP: a lightweight database of human nonsynonymous SNPs and their functional predictions. Hum Mutat 2011, 32(8):894-899.

22. Larkin MA, Blackshields G, Brown NP, Chenna R, McGettigan PA, McWilliam H, Valentin F, Wallace IM, Wilm A, Lopez R, et al: Clustal W and Clustal X version 2.0. Bioinformatics 2007, 23(21):2947-2948.

23. Vemula SR, Puschmann A, Xiao J, Zhao Y, Rudzinska M, Frei KP, Truong DD Wszolek ZK, LeDoux MS: Role of Ga(olf) in familial and sporadic adultonset primary dystonia. Hum Mol Genet 2013, 22(12):2510-2519.

24. Ng PC, Henikoff S: SIFT: Predicting amino acid changes that affect protein function. Nucleic Acids Res 2003, 31(13):3812-3814

25. Adzhubei IA, Schmidt S, Peshkin L, Ramensky VE, Gerasimova A, Bork P Kondrashov AS, Sunyaev SR: A method and server for predicting damaging missense mutations. Nat Methods 2010, 7(4):248-249.

26. Schwarz JM, Rödelsperger C, Schuelke M, Seelow D: MutationTaster evaluates disease-causing potential of sequence alterations. Nat Methods 2010, 7(8):575-576.

27. Nicoloso MS, Sun H, Spizzo R, Kim H, Wickramasinghe P, Shimizu M, Wojcik SE, Ferdin J, Kunej T, Xiao L, et al: Single-nucleotide polymorphisms inside microRNA target sites influence tumor susceptibility. Cancer Res 2010, 70(7):2789-2798. 
28. Silva SN, Tomar M, Paulo C, Gomes BC, Azevedo AP, Teixeira V, Pina JE, Rueff J, Gaspar JF: Breast cancer risk and common single nucleotide polymorphisms in homologous recombination DNA repair pathway genes XRCC2, XRCC3, NBS1 and RAD51. Cancer Epidemiol 2010, 34(1):85-92.

29. LeDoux MS: The genetics of dystonias. Adv Genet 2012, 79:35-85

30. Ozelius LJ, Hewett JW, Page CE, Bressman SB, Kramer PL, Shalish C, de Leon D, Brin MF, Raymond D, Corey DP, et al: The early-onset torsion dystonia gene (DYT1) encodes an ATP-binding protein. Nat Genet 1997, 17(1):40-48

31. Charlesworth G, Plagnol V, Holmström KM, Bras J, Sheerin UM, Preza E, Rubio-Agusti I, Ryten M, Schneider SA, Stamelou M, et al: Mutations in ANO3 cause dominant craniocervical dystonia: ion channel implicated in pathogenesis. Am J Hum Genet 2012, 91(6):1041-1050.

32. Fuchs T, Saunders-Pullman R, Masuho I, Luciano MS, Raymond D, Factor S, Lang AE, Liang TW, Trosch RM, et al: Mutations in GNAL cause primary torsion dystonia. Nat Genet 2013, 45(1):88-92.

33. Hersheson J, Mencacci NE, Davis M, Macdonald N, Trabzuni D, Ryten M, Pittman A, Paudel R, Kara E, Fawcett K, et al: Mutations in the autoregulatory domain of $\beta$-tubulin 4 a cause hereditary dystonia. Ann Neurol 2012. Dec 13. [Epub ahead of print] PubMed PMID: 23424103.

34. Burke RE, Fahn S, Jankovic J, Marsden CD, Lang AE, Gollomp S, Ilson J: Tardive dystonia: late-onset and persistent dystonia caused by antipsychotic drugs. Neurol 1982, 32(12):1335-1346.

35. Calakos N, Patel VD, Gottron M, Wang G, Tran-Viet KN, Brewington D, Beyer $J$, Steffens DC, Krishnan RR, Zuchner S: Functional evidence implicating a novel TOR1A mutation in idiopathic, late-onset focal dystonia. J Med Genet 2010, 47(9):646-650.

36. Lee HJ, Kang SG: Genetics of tardive dyskinesia. Int Rev Neurobiol 2011, 98:231-264

37. Cohen OS, Hassin-Baer S, Spiegelmann R: Deep brain stimulation of the internal globus pallidus for refractory tardive dystonia. Parkinsonism Relat Disord 2007, 13(8):541-544.

38. Krauss JK: Deep brain stimulation for dystonia in adults. Overview and developments. Stereotact Funct Neurosurg 2002, 78(3-4):168-182.

39. Vidailhet $M$, Vercueil $L$, Houeto $J$, Krystkowiak P, Benabid AL, Cornu P, Lagrange C, Tezenas Du Montcel S, Dormont D, Grand S, et al: Bilateral deep-brain stimulation of the globus pallidus in primary generalized dystonia. N Engl J Med 2005, 352(5):459-467.

40. Kupsch A, Benecke R, Muller J, Trottenberg T, Schneider GH, Poewe W, Eisner W, Wolters A, Muller JU, Deuschl G, et al: Pallidal deep-brain stimulation in primary generalized or segmental dystonia. N Engl J Med 2006, 355(19):1978-1990.

41. Isaias IU, Alterman RL, Tagliati M: Outcome predictors of pallidal stimulation in patients with primary dystonia: the role of disease duration. Brain 2008, 131(Pt 7):1895-1902.

42. Tagliati M, Shils J, Sun C, Alterman R: Deep brain stimulation for dystonia. Expert Rev Med Devices 2004, 1(1):33-41.

43. Hong X, Tsai HJ, Liu X, Li Z, Tang G, Xing H, Yang J, Wang B, Feng Y, Xu X, et al: A large-scale genome-wide linkage analysis to map loci linked to stature in Chinese population. J Clin Endocrinol Metab 2008, 93(11):4511-4518.

44. Mefford HC, Sharp AJ, Baker C, Itsara A, Jiang Z, Buysse K, Huang S, Maloney VK Crolla JA, Baralle D, et al: Recurrent rearrangements of chromosome 1q21.1 and variable pediatric phenotypes. N Engl J Med 2008, 359(16):1685-1699.

45. Girirajan S, Eichler EE: Phenotypic variability and genetic susceptibility to genomic disorders. Hum Mol Genet 2010, 19(R2):R176-R187.

46. Girirajan S, Brkanac Z, Coe BP, Baker C, Vives L, Vu TH, Shafer N, Bernier R, Ferrero GB, Silengo $M$, et al: Relative burden of large CNVs on a range of neurodevelopmental phenotypes. PLoS Genet 2011, 7(11):e1002334.

47. Rosenfeld JA, Coe BP, Eichler EE, Cuckle H, Shaffer LG: Estimates of penetrance for recurrent pathogenic copy-number variations. Genet Med 2012. Dec 20. doi: 10.1038/gim.2012.164. [Epub ahead of print] PubMed PMID: 23258348

48. Hippisley-Cox J, Vinogradova Y, Coupland C, Parker C: Risk of malignancy in patients with schizophrenia or bipolar disorder: nested case-control study. Arch Gen Psychiatry 2007, 64(12):1368-1376.

49. Chen LL, Carmichael GG: Decoding the function of nuclear long non-coding RNAs. Curr Opin Cell Biol 2010, 22(3):357-364.
50. Shen $C$, Huang $Y$, Liu $Y$, Wang G, Zhao $Y$, Wang $Z$, Teng $M$, Wang $Y$, Flockhart DA, Skaar TC, et al: A modulated empirical Bayes model for identifying topological and temporal estrogen receptor alpha regulatory networks in breast cancer. BMC Syst Biol 2011, 5:67.

51. Tian Y, Stamova B, Jickling GC, Liu D, Ander BP, Bushnell C, Zhan X, Davis $R R$, Verro P, Pevec WC, et al: Effects of gender on gene expression in the blood of ischemic stroke patients. J Cereb Blood Flow Metab 2012, 32(5):780-791.

doi:10.1186/1471-2350-14-70

Cite this article as: Moscovich et al:: Dystonia, facial dysmorphism, intellectual disability and breast cancer associated with a chromosome $13 q 34$ duplication and overexpression of TFDP1: case report. BMC Medical Genetics 2013 14:70.

\section{Submit your next manuscript to BioMed Central and take full advantage of:}

- Convenient online submission

- Thorough peer review

- No space constraints or color figure charges

- Immediate publication on acceptance

- Inclusion in PubMed, CAS, Scopus and Google Scholar

- Research which is freely available for redistribution

Submit your manuscript at www.biomedcentral.com/submit
C) Biomed Central 